SciDioc

\section{Why HDFx, a Stress Protein, May Ameliorate the Pig-Plague Effects of The African Swine Flu Virus (ASFV)}

Editorial

Burton M. Altura ${ }^{1-6^{*}}$

${ }^{1}$ Department of Physiology and Pharmacology,

${ }^{2}$ Department of Medicine,

${ }^{3}$ The School of Graduate Studies in Molecular and Cellular Science,

${ }^{4}$ SUNY Downstate Health Sciences University, Brooklyn, New York;

${ }^{5}$ Bio-Defense Systems, Inc, Rockville Centre, New York;

${ }^{6}$ Orient Biomedica, Estero, Florida.

\section{Introduction}

In 1921, Robert Montgomery, working in Kenya, noticed that pigs brought from England quickly developed a contagious pneumonia and rapidly succumbed, and died [1]. When antibodies against African Swine Flu Virus (ASFV) were developed (which promoted swine fever and caused feverish chills), andfailed to promote any protection, scientists concluded that another virus, that later was characterized as ASFV must be responsible for the contagion [2]. Although ASFV is harmless in humans, so far, it can be extremely dangerous in pigs [1]. Infection in pigs usually causes death with a hemorrhagic fever in one week, akin to Ebola and Marburg virus fevers. ASFV has killed hundreds of thousands of pigs in China, The Philippines, South Korea, Vietnam, Laos, Mongolia, Cambodia, Myanmar, Africa, and eastern Europe [3]. It is thought that ASFV will kill about a quarter of the world's pig population over the next few years due to lack of a vaccine. Discovery of a vaccine or a workable ameliorative would aid farmers and the civilian population immensely.

ASFV typically invades macrophages, monocytes and other blood-formed elements, thus making host-defense problematical. These invasive cellular effects induce a massive number of inflammatory responses along with hemorrhages, particularly in the lungs [1-3]. Moreover, ASFV leads to cell death of macrophages, monocytes, leukocytes and endothelial cells [3]. The major cell types that seem to be needed in defense against ASFV are the "killer T-cells", but these important cell types appear to be inactivated or destroyed early after infection by ASFV [3]. Although a considerable amount of time and effort seems to have been spent trying to develop a reliable vaccine against ASFV, this has been fruitless in many respects [3]. Manuel Boron, at The Plum Island Animal Disease Center in the USA, has developed some interest- ing vaccines, but safety has turned out to be a major problem with each of four vaccines [3]. Although new approaches to development of gene-deleted vaccines are thought to be a good way for successful vaccines against ASFV, so far this has not resulted in a viable vaccine [3].

For a number of years, our laboratories have been working on peptides/small proteins, lipids and other molecules which stimulate the innate and adaptive immune systems [4-33]. Along the way, we have found and isolated a $35-40 \mathrm{kD}$ conserved stress protein that is in the bodies of all mammals, including rats, rabbits, mice, guinea-pigs, dogs, cats, monkeys, baboons, and pigs that we have termed host defense factor x (i.e., HDFx) [34]].

\section{Discovery and Physiological Attributes of HDFx}

About 135 years ago, Elie Metchnikoff , the father of immunology, using injury of starfish, hypothesized that the body under stressful and injurious circumstances would produce powerful immunological stimulants which could act on different parts of the immune system and serve to protect the host against major, dangerous insults, inflammatory conditions, wounding, and diverse diseases [35]]. Metchnikoff's early studies pointed to the important contribution of macrophages and phagocytic leukocytes in natural (innate) resistance against pathogenic microorganisms. Over the past 65 years much work has been done to indicate a strong support to demonstrate an important, physiological relationship between the microcirculation, macrophages, phagocytic leukocytes, alveolar macrophages, splenic macrophages, natural killer (NK) cells, the reticuloendothelial cells (particularly Kupffer cells) ,and "pit cells" in the liver to host defense [4-33, 36-39].

Using Metchnikoff's hypothesis, and thousands of animals, we

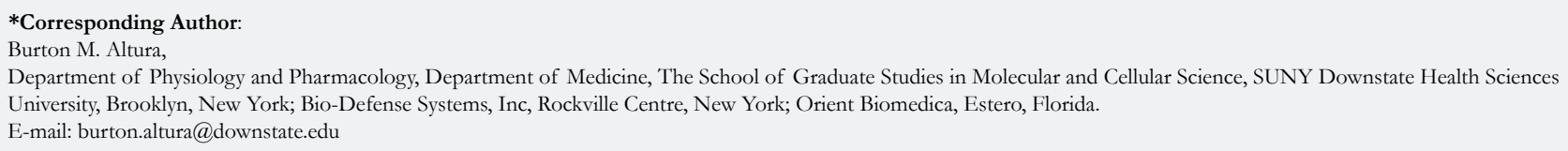

Copyright: Burton M. Altura ${ }^{\circ}$ 2020. This is an open-access article distributed under the terms of the Creative Commons Attribution License, which permits unrestricted use, distribution and reproduction in any medium, provided the original author and source are credited. 
found that diverse, injurious insults, for example, sublethal hemorrhage, sublethal intestinal ischemic shock, endotoxins, live bacteria (i.e., E. coli, S. enteriditis), sublethal centripetal forces, trauma, circulatory shock, and combined injuries, would produce a 35-40 kD conserved protein (i.e., HDFx) which when isolated, purified and administered to diverse mammals resulted in protection (or amelioration) against these diverse forms of deadly injuries [4, 34-39].

Unique attributes of HDFx, not to be minimized, is its ability to : 1. Accelerate wound healing; 2 . Restore transcapillary blood flows towards normal in injured and inflamed tissues (e.g., in lungs, kidneys, liver); 3. Restore vasomotor tone; 4 . Restore lowered arterial blood pressures towards normal; and 5. Restore endotoxininduced fevers towards normal [4, 5]. Very importantly, we have found that HDFx can ameliorate/prevent "cytokine storms" in numerous rodents and farm animals, similar to those found in ASFV [4, 40, 42].

\section{HDFx and its Potential to Ameliorate the Deadly} Effects of "Superbugs" and Possibly ASFV: Importance of Activated Macrophages and NK Cells

Most hospital-induced infections in humans are caused by gramnegative bacteria $[38,39]$. These "superbug -induced infections "are not only found in humans but diverse "superbug" gramnegative and gram-positive bacteria, as well as numerous funguses and viruses which are found to cause deadly infectious diseases in domestic as well as farm animals [39]. Since HDFx "supercharges" macrophages, NK cells, phagocytic leukocytes and Kupffer cells, in all mammals we have investigated, including pigs [4, 5], it is our belief that HDFx would detoxify/prevent ASFV from causing pathologies in the lung s, kidneys and liver, and prevent/ ameliorate "cytokine storms", thus preventing or eradicating AS$\mathrm{FV}$-induced drops in arterial blood pressure and elevated episodes of steep rises in body temperature; prevent or ameliorate alveolar tissue, liver and renal tissue damage due to its ability to improve transcapillary nutritive blood flows, and lastly,Its ability to accelerate healing and regeneration [4, 5, 40-42]. Whether HDFx will preserve "killer T-cells" remains to be investigated. To myknowledge, HDFx is the only host-defense molecule that embodies all of these unique attributes and vital therapeutic qualities against "superbugs". Moreover, since ASFV is a hemorrhagic fever,and HDFx is thought to meliorate some hemorrhagic fevers [43], we believe it would be propitious to test HDFx's effectiveness on hundreds of infected pigs.

\section{Conclusions and Future Thoughts}

It is rather obvious that the deadly ASFV could wreak havoc worldwide should this "superbug" become airborne or mutated to infect humans like has happened with Ebola, Lassa, Nipah and other viruses through mutations. Moreover, if ASFV becomes airborne and mutated, the costs to farmers and the public worldwide could bankrupt populations and interfere with critical food supplies. This potential disaster becomes "a clear and present danger" to human-kind which demands immediate action by the UN, WHO, USDA, and CDC's. Since the specific molecular mechanisms of action for infection by ASFV (and its rapid deadly effects) are not known, after more than 100 years of research, we believe HDFx should be tried against the bodily actions of ASFV.

\section{Acknowledgements}

Over the years, our HDFx research has been supported, in part, by research grants from The National Heart, Lung and Blood Institute and unrestricted grants-in-aid from several pharmaceutical companies. Early on in ourinvestigations on HDFx, Professor Solomon G. Hershey was extremely helpful in donating some funding for our research. Some of our research efforts have also been supported by a grant from The Bio-Defense Laboratories at The U.S. Naval Hospital, Silver Springs, MD.

\section{References}

[1]. Montgomery RE. On a form of swine fever occurring in British East Africa (Kenya Colony). Journal of comparative pathology and therapeutics. 1921 Jan 1;34:159-91.

[2]. Stone SS, Hess WR. Antibody response to inactivated preparations of African swine fever virus in pigs. Am J Vet Res. 1967; 28: 475-481. PMID: 4291851 .

[3]. Zimmer K. Pig Plague. SCIENTIST. 2020 Jan 1;34(1):22-9.

[4]. Hershey SG, Altura BM. Effects of pretreatment with aggregate human albumin on the reticuloendothelial system activity and after experimental shock. Proc Soc exp Biol Med. 1966; 122: 1195-1199. PMID: 5918141.

[5]. Altura BM, Hershey SG. Use of reticuloendothelial phagocytic function as an index in shock therapy. Bull NY Acad Med. 1967; 43: 259-266. PMID: 5232488 .

[6]. Altura BM, Hershey SG. RES phagocytic function in trauma and adaptation to experimental shock. Am J Physiol. 1968; 215: 1414-1419. PMID: 5723004 .

[7]. Altura BM, Hershey SG. Influence of vasopressor drugs on reticuloendothelial phagocytic function in experimental shock. Intermedes Proceedings. 1968:185-93.

[8]. Hershey SG, Altura BM. Influence of RES stimulating materials compatible for man on phagocytosis and survival after experimental shock. Intermedes Proceedings. 1968:195-213.

[9]. Altura BM, Hershey SG. Patterns of RES phagocytic function in trauma and experimental adaptation. Intermedes Proceedings 1968: Combined Injuries and Shock. 1968:205-13.

[10]. Hershey SG, Altura BM. Function of the reticuloendothelial system in experimental shock and trauma. Anesthesiology. 1969; 30: 138-143. PMID: 5765377.

[11]. Hershey SG, Altura BM.The effects of vasoactive drugs on reticuloendothelial function in experimental shock and combined injury. Anesthesiology. 1969; 30: 144-149. PMID: 4303856.

[12]. Altura BM, Hershey SG. Effects of glycerol trioleate on the reticuloendothelial system and after experimental shock. J Pharmacol Exp Ther. 1970;175: 555-564. PMID: 5489914.

[13]. Altura BM, Hershey SG. Acute intestinal ischemia shock and reticuloendothelial system function. J Reticuloendothelial Soc. 1971; 10(4): 361-371. PMID: 5097619.

[14]. Altura BM, Hershey SG. Sequential changes in reticuloendothelial system function after acute hemorrhage. Proc Soc Exp Biol Med. 1972; 139: $935-$ 939. PMID: 5023782.

[15]. Altura BM, Hershey SG. Reticuloendothelial function in experimental injury and tolerance to shock. InNeurohumoral and Metabolic Aspects of Injury, Springer, Boston, MA. 1973; 545-569.

[16]. Altura BM, Altura BT.Peripheral vascular effects of glucorticoids and their relationship to protection in circulatory shock. J Pharmacol Exp Ther. 1974; 190: 300-315. PMID: 4449042.

[17]. Halevy S, Altura BM. Genetic factors influencing resistance to trauma. Circulatory Shock. 1974 Jan 1;1(4):287-93.

[18]. Altura BM. HEMORRHAGIC-SHOCK AND RETICULOENDOTHELIAL SYSTEM PHAGOCYTIC FUNCTION IN PATHOGEN-FREE ANIMALS. Circulatory Shock. 1974 Jan 1;1(4):295-300.

[19]. Altura BM, Altura BT, Hershey SG. Pharmacodynamic actions of corticosteroids on the microcirculation and vascular smooth muscle. Steroids and Shock, ed Glenn TM, University Park Press, Baltimore, MD. 1974:67-88.

[20]. Altura BM. DPAVP: A vasopressin analog with selective microvascular and RES actions for the treatment of circulatory shock in rats. Eur J Pharmacol. 1976; 37: 155-168. PMID: 1278238.

[21]. Altura BM. Microcirculatory approach to the treatment of circulatory shock using a new analog of vasopressin, [2-phenylalanine, 8-ornithine]-vasopres- 
sin. J Pharmacol Exp Ther. 1976; 198:187-196. PMID: 933006.

[22]. Altura BM. Sex and estrogens in protection against circulatory stress reactions. Am J Physiol. 1976; 231: 842-847. PMID: 970465.

[23]. Altura BM. Reticuloendothelial and neuro-endocrine stimulation in shock therapy. Adv Shock Res. 1980; 3:3-25. PMID: 7030014.

[24]. Altura BM. Recent progress in pathophysiology of shock: Reticuloendothelial and neuro-endocrine stimulation. J Clin Anesth. 1980;4(29):305-16.

[25]. Altura BM. Reticuloendothelial cells and host defense. Adv Microcirc. 1980;9:252-94.

[26]. Altura BM. Pathophysiology of the reticuloendothelial system. Raven Press; New York 1981.

[27]. Altura BM. Reticuloendothelial system function and histamine release in shock and trauma: relationship to microcirculation. KlinischeWochenschrift. 1982 Sep 1;60(17):882-90.

[28]. Halevy S, Altura BM, Altura BT. Pathophysiologic basis for the use of steroids in the treatment of shock and trauma. KlinWochenschr. 1982; 60: 1021-1030. PMID: 7132241.

[29]. Altura BM (1985) Role of reticuloendothelial and endothelial cells in response to shock and trauma. In: Pathophysiology of Combined Injuries and Trauma, Conklin JT, ed. University Park Press, Baltimore.

[30]. Altura BM (1985) Microcirculatory regulation and dysfunction: relation to RES function and tolerance to shock and trauma. In: The Reticuloendothelial System, 7B, Reichard SM, Filkins JP, eds. Plenum Press, New York, 355-395.

[31]. Altura BM (1986) Endothelial and reticuloendothelial cell function: roles in injury and low-flow states. In: The Scientific Basis for the Care of the Critically Ill, Little RA, Frayn KN, eds. Manchester Univ Press, Manchester, The UK, 259-274.

[32]. Altura BM, Gebrewold A, Carella A, Altura BT. Synthetic Vasopressin and Oxytocin Analogs and Their Potential Use in Hemorrhagic, Traumatic and Septic Shock: A Personal Perspective. Int J Surg Res. 2017 Jun 7;4:1-3.

[33]. Altura BM, Gebrewold A, Carella A, Altura BT. Why Synthetic Vasopressin and Oxytocin Analogs Should be Considered in the Treatment of Cardiogenic Shock: A Personal Perspective. Clin Surg. 2018;3:1943.

[34]. Altura BM, Gebrewold A, Carella A. A novel biologic immunomodulator, HDFx, protects against lethal hemorrhage, endotoxins and traumatic injury: potential relevance to emerging diseases. Int j Clin Exp Med. 2009; 2(3): 266-279. PMID: 19918319.

[35]. Metchnikoff E (1881) Untersuchungueber die intracellulareVerddanuungbeiwirbeibeliosenThieren. Arb Zool Inst Wien 5: 141-168.

[36]. Zweifach BW, Thomas L. The relationship between the vascular manifestations of shock produced by endotoxin, trauma and hemorrhage. J Exp Med. 1957Sep 1;106(3):385-401. PMID: 13463249. DOI: 10.1084/ jem.106.3.385.

[37]. Zweifach BW. The contribution of the reticuloendothelial system to the development of tolerance to experimental shock. Ann Ny Acad Sci. 1960:88:203-12. PMID: 13789019.

[38]. Majno G, Joris I (2004) Cells, Tissues, and Disease: Principles of General Pathology, 2nd Ed. Oxford Univ Press, New York.

[39]. Murphy K, Weaver C (2018) Janeways Immunobiology 10th Ed. Garland Publ Co., New York

[40]. Altura BM, Gebrewold A, Carella A, Altura BT.HDFx: A novel immunomodulator and potential fighter against cytokine storms in inflammatory and septic conditions in dogs and farm animals. Int J Vet Health \& Sci. 2017: 5(2e): 1-3. DOI: http://dx.doi.org/10.19070/2332-2748-170006e.

[41]. Altura BM , Gebrewold A, Carella A (2020) HDFx\& transferal of plasma from animals that survive lethal hemorrhage, bowel ischemic shock, endotoxins, centripetal forces or body trauma to naïve animals induces crossresistance to these various experimental forms of injury and trauma: Importance of macrophages, NK cells and relevance to design of molecules to treat/ameliorate effects of corona viral diseases. EC Emergency Med \& Care, in press.

[42]. Altura BM,Gebrewold A, Carella (2020) HDFx, A new stress-induced protective protein that may ameliorate infections caused by coronaviruses like COVID-19, SARS and MERS; Importance of immune-competent NK cells, macrophages, and T-lymphocytes. EC Pharmacol\&Toxicol, in press.

[43]. Altura BM, Gebrewold A, Carella A. HDFx: A recently discovered biologic and its potential use in prevention and treatment of hemorrhagic fever viruses and antibiotic-resistant superbugs. J HematolThrombo Dis. 2016;4(252):2. 